\title{
EFFECT OF EMOTIONAL INTELLIGENCE AND EMOTIONAL MATURITY ON ALTRUISTIC BEHAVIOR IN ADOLESCENTS
}

\author{
Silpa Balagangadharan ${ }^{1}$, Akhil. S.S ${ }^{2}$, Anakha E ${ }^{3}$ \\ ${ }^{1} \mathrm{PhD}$ Scholar, Department of Psychology, University of Kerala, Trivandrum, India \\ ${ }^{2}$ MPhil student, Department of Psychology, Sree Sankaracharya University of Sanskrit, India \\ ${ }^{3}$ PG student, Department of Psychology, Sree Sankaracharya University of Sanskrit, Kalady, India
}

\begin{abstract}
The first objective of the current study was to investigate the relationship between emotional intelligence and emotional maturity on altruistic behavior in adolescents. There are several reasons to postulate such a relationship. First, Roberts and Strayer (1996) showed a directional link from emotional insight or the ability to recognize one's own emotions, to empathy, and from empathy to prosocial behaviors in children in three age groups ( 5 yr. olds, 9 yr. olds, and 13 yr. olds). Similarly, Trobst, Colls, and Embree (1994) reported a correlation between empathy and intention to provide social support for a sample of university students. Thus, because emotional intelligence is conceptually associated with empathy and because empathy has been linked to prosocial behaviors, it is plausible there may be an association for emotional intelligence with prosocial behaviors. The study is 'Effect of emotional intelligence and emotional maturity on altruistic behavior in adolescents'. The sample size was determined by purposive sampling method $(\mathrm{n}=140)$. In this study three standard questionnaires of Emotional intelligence scale, Emotional maturity scale, Altruistic behavior questionnaire respectively were used. The reliability and validity of these three instruments were reported to be significant in different studies. The findings indicated that there was a significant negative correlation between emotional intelligence and emotional maturity-social maladjustment, no significant correlation between emotional intelligence and altruistic behavior of the participants.
\end{abstract}

Keywords: Emotional intelligence, Emotional maturity, Altruistic behavior

\section{INTRODUCTION}

"Developmental shift from childhood selfishness towards more social altruism in adolescence offers clues about how to build more supportive societies." In adolescence children's brains change, making them generous to insiders but more hostile to outsiders. It is well-known that young children find it difficult to share but become more generous as they grow older. Studies have confirmed that, during adolescence, people do indeed become more altruistic towards those in their social network. However, they simultaneously become more 'parochial' - less generous and more spiteful - towards outsiders. Egalitarianism loses its dominance among adolescents, for whom altruism becomes prevalent towards people close to them. We observed a growing difference in the treatment of in-group and out-group members during adolescence like, envy towards out-group members grew significantly stronger from the age of 12 or 13 onwards. In order to influence human altruistic behavior during adolescence, it is important to know the typical baseline levels and developmental patterns of altruistic behavior. Thoughtful interventions need to be based on a lot of pre-existing knowledge. We might be able to alter parenting styles, how teachers work with children, how peers interact or how business cultures behave in order to influence greater prosocial behavior in children. Emotional intelligence is a construct that is still evolving, having emerged in the last two decades. Mayer and Salovey (1997) define emotional intelligence as "the ability to perceive emotions, to access and generate emotions so as to assist thought, to understand emotions and emotional knowledge, and to reflectively regulate emotions so as to promote emotional and intellectual growth". In other words, emotional intelligence refers to one's ability to understand and influence one's own and other's emotions and to control the emotional content imbedded in various situations. At least one aspect of emotional intelligence, namely, the ability to recognize emotions in others, is closely related to empathy by definition (Salovey \& Mayer, 1990; Golernan, 1995). The exact nature of the emotional intelligence construct is still under debate, with some saying it meets traditional standards for an intelligence (Ciarrochi, Chan, \& Caputi, 2000; Mayer, Caruso, \& Salovey, 2000) and others who claim it is not an intelligence (Davies, Stankov, \& Roberts, 1998). Nevertheless, its influence on leadership abilities (Barhg, Slater, \& Kelloway, 2000), on goal orientation, life satisfaction, and depression (Martinez-Pons, 1997), and on relationship quality 


\section{International Advanced Research Journal in Science, Engineering and Technology}

Vol. 8, Issue 6, June 2021

DOI: $10.17148 /$ IARJSET.2021.86115

(Ciarrochi, 2000) in adults testifies to its importance. Goleman (1995) claimed that emotional intelligence develops early in life, so it may be possible that the construct could be useful in studies on adolescents.

In the present circumstances, youth as well as children are facing difficulties in life. These difficulties are giving rise to many psycho-somatic problems such as anxiety, tensions, frustrations and emotional upsets in day to day life. So, the study of emotional life is now emerging as a descriptive science, comparable with anatomy. Genes and hormones play a vital role in overall growth and development of Children and adolescents. Beyond adolescence, an individual has to choose maturity. An individual can learn emotional intelligence but emotional maturity is a matter of choice. So it has to be made consciously, otherwise an individual will not be able to move beyond the emotional immaturity of an adolescent despite any and all trappings of material "success". The two major characteristics of children and adolescents are Selfcenteredness and self-importance. They demand special attention and care and want to do some real contributions themselves. They complain of indifference to their demands and needs. This does not make them "bad." This is a significant aspect of their maturation process. However, these behaviors are not the qualities of the emotionally mature. In fact, there is a lot of people who "look grown up" and behave as rational by contemporary standards, but emotionally they behave like children. There are five major functions of emotional maturity namely, emotional instability, emotional regression, social maladjustment, personal disintegration and lack of independence. Family plays an important role in the educational and vocational progress of the children. Roe (1957) hypothesized that three types of parental attitudesacceptance, concentration and avoidance are associated with the vocational development of the students. On account of these attitudes which parents show towards their son and daughter, they develop certain attitudes towards the home environment.

The formation of attitude in the early stages of life plays a significant role in the developmental process of individuals. Researchers have exerted much on various aspects of individual's life responsible for the growth in the later stages of life but have not taken any step in developing certain models which determine the condition of home environment for future development. Parental attitude also plays a significant role in the psychological development of adolescents. There are three major dimensions of perceived parental attitudes, namely, acceptance, concentration and avoidance. Acceptance means that the parents consider the child as a full-fledged member of the family who needs a certain degree of independence and who has the capacity to assume responsibility. Concentration refers to attitudes of parents who devote a disproportionate amount of their time and energy to the direction and control of their children. Avoidance characterizes the disposition of parents who either neglect or reject the child.

Adolescence marks the change and expansion in the dimensions of responsibilities of an individual. He considers himself to be an adult and wants to be treated in the same manner and with the same respect. Adolescents are held responsible for own acts. Family plays an important role here. They help in the development of confidence, will to shoulder responsibilities and fulfill their duties. It always specifies the limits of their freedom, abilities and potentialities to undertake every work in the best possible manner. An individual who grows in such an environment is capable of adjustment and achieving his goals in a better and determined way. Such family surrounding and attitude help in the emotional development of the child and increase his capacity of adjustment.

\subsection{Hypotheses to be tested}

1. There is significant difference on the basis of age in altruistic behavior, emotional intelligence and emotional maturity in adolescence.

2. There is significant difference on the basis of gender in altruistic behavior, emotional intelligence and emotional maturity in adolescence.

3. There is significant difference on the basis of area of residence in altruistic behavior, emotional intelligence and emotional maturity in adolescence.

4. There is significant difference on the basis of family income in altruistic behavior, emotional intelligence and emotional maturity in adolescence.

5. There is significant difference on the basis of religion in altruistic behavior, emotional intelligence and emotional maturity in adolescence.

6. There is significant difference on the basis of type of institution in altruistic behavior, emotional intelligence and emotional maturity in adolescence.

7. There is significant relationship between emotional intelligence and altruistic behavior in adolescence.

8. There is significant relationship between emotional maturity and altruistic behavior in adolescence. 


\section{International Advanced Research Journal in Science, Engineering and Technology}

Vol. 8, Issue 6, June 2021

DOI: $10.17148 /$ IARJSET.2021.86115

\section{METHOD}

To examine the effects of emotional intelligence and emotional maturity on altruistic behavior in adolescence, also to investigate whether factors such as age, gender, family income, religion, type of family influence the variables. This study is descriptive- correlative. The statistical sample of the study is a conveniently chosen one consisting of 140 students of age 13 - 19 from various parts of Trivandrum. Due representation was given to age, gender, family income, religion, type of family. The study intends to measure altruistic behavior, emotional intelligence and emotional maturity in adolescence. The tools used for this study are Emotional intelligence scale [Jayaraj B and dr. h. Sam Sanandharaj(1998)], Emotional maturity scale [dr. Yashvir singh and dr. Mahesh Bhargava (1998)] Altruistic behavior index [sreekumar. R. and dr. h. Sam Sanandharaj(1998)]. Above Psychological devices were simultaneously administered to the subject personally and they were asked to read carefully the instructions and answer all the questions correctly without omitting any. Although data were collected from 187 participants, only 140 were found to be complete and hence used for the analysis. The collected response was scored according to the scoring procedures provided for each tool. The data collected were analyzed using statistical technique of Pearson correlation method and Duncan test.

\section{RESULTS}

The findings of the descriptive study are as shown in the following tables:-

\subsection{Post Hoc Tests}

\begin{tabular}{|c|c|c|c|c|c|}
\hline \multirow[t]{2}{*}{ AGE } & \multirow[t]{2}{*}{$\mathrm{N}$} & \multicolumn{4}{|c|}{ Subset for alpha $=0.05$} \\
\hline & & 1 & 2 & 3 & 4 \\
\hline $\begin{array}{c}16 \\
18 \\
19 \\
17 \\
14 \\
15 \\
13 \\
\text { Sig. }\end{array}$ & $\begin{array}{l}20 \\
20 \\
20 \\
20 \\
20 \\
20 \\
20\end{array}$ & $\begin{array}{l}61.85 \\
63.90 \\
66.10 \\
69.45 \\
\\
.084\end{array}$ & $\begin{array}{l}63.90 \\
66.10 \\
69.45 \\
71.60 \\
.080\end{array}$ & $\begin{array}{l}66.10 \\
69.45 \\
71.60 \\
72.75 \\
.131\end{array}$ & $\begin{array}{l}83.80 \\
1.000\end{array}$ \\
\hline
\end{tabular}

EMER

\begin{tabular}{|c|c|c|c|}
\hline \multirow{2}{*}{ AGE } & N & \multicolumn{2}{|c|}{ Subset for alpha $=0.05$} \\
\cline { 3 - 4 } & & 1 & 2 \\
\hline 15 & 20 & 22.55 & 23.70 \\
14 & 20 & 23.70 & 23.75 \\
18 & 20 & 23.75 & 23.80 \\
17 & 20 & 23.80 & 24.10 \\
13 & 20 & 24.10 & 24.10 \\
16 & 20 & 24.10 & 25.70 \\
19 & 20 & & .133 \\
Sig. & & .247 & \\
\hline
\end{tabular}

EMSM

\begin{tabular}{|c|c|c|c|c|}
\hline \multirow{2}{*}{ AGE } & \multirow{2}{*}{$\mathrm{N}$} & \multicolumn{3}{|c|}{ Subset for alpha =0.05 } \\
\cline { 3 - 5 } & & 1 & 2 & 3 \\
\hline 15 & 20 & 20.25 & & \\
14 & 20 & 20.40 & 22.65 & \\
17 & 20 & & 23.65 & \\
13 & 20 & & 24.10 & 23.65 \\
19 & 20 & & 24.65 & 24.10 \\
18 & 20 & & & 24.65 \\
16 & 20 & & .100 & 25.45 \\
Sig. & & .892 & & .140 \\
\hline
\end{tabular}


Vol. 8, Issue 6, June 2021

DOI: $10.17148 /$ IARJSET.2021.86115

EMPD

\begin{tabular}{|c|c|c|c|}
\hline \multirow[t]{2}{*}{ AGE } & \multirow[t]{2}{*}{$\mathrm{N}$} & \multicolumn{2}{|c|}{ Subset for alpha $=0.05$} \\
\hline & & 1 & 2 \\
\hline 14 & 20 & 20.80 & \\
\hline 13 & 20 & 21.60 & 21.60 \\
\hline 15 & 20 & 22.55 & 22.55 \\
\hline 17 & 20 & 22.60 & 22.60 \\
\hline 16 & 20 & & 23.40 \\
\hline 19 & 20 & & 23.80 \\
\hline 18 & 20 & & 23.90 \\
\hline Sig. & & .153 & .079 \\
\hline
\end{tabular}

EMLI

\begin{tabular}{|c|c|c|c|c|}
\hline AGE & \multirow{2}{*}{$\mathrm{N}$} & \multicolumn{3}{|c|}{ Subset for alpha = 0.05 } \\
\cline { 3 - 5 } & & 1 & 2 & 3 \\
\hline 19 & 20 & 19.35 & 21.80 & \\
16 & 20 & & 21.85 & \\
18 & 20 & & 22.00 & \\
15 & 20 & & 22.10 & \\
14 & 20 & & 23.00 & 23.00 \\
17 & 20 & & & .073 \\
13 & 20 & \multirow{2}{*}{1.000} & .305 & \\
& & & & \\
\hline
\end{tabular}

\subsection{Correlations}

\begin{tabular}{|c|c|c|c|c|c|c|c|}
\hline & $\mathrm{AB}$ & EI & EMEU & EMER & EMSM & EMPD & EMLI \\
\hline $\begin{array}{c}\text { AB } \\
\text { EI } \\
\text { EMEU } \\
\text { EMER } \\
\text { EMSM } \\
\text { EMPD } \\
\text { EMLI }\end{array}$ & $\begin{array}{l}.033 \\
.109 \\
-.043 \\
-.033 \\
-.137 \\
-.008\end{array}$ & $\begin{array}{c}.028 \\
.025 \\
-.193 * \\
-.078 \\
.073\end{array}$ & $\begin{array}{l}-.142 \\
-.073 \\
-.109 \\
.000\end{array}$ & $\begin{array}{c}.205^{*} \\
.036 \\
-.167^{*}\end{array}$ & $\begin{array}{l}.079 \\
.019\end{array}$ & $-.254 * *$ & \\
\hline
\end{tabular}

\section{DISCUSSION AND CONCLUSION}

The coefficient of correlation obtained between emotional intelligence and one of the sub variables that comes under emotional maturity shows that there is significant correlation between the two variables. The correlation is negative in direction indicating inverse relationship between them as when emotional intelligence increases, the emotional maturitysocial maladjustment tends to decrease accordingly. Also significant difference can be seen for emotional intelligence, emotional regression, social maladjustment, personality disintegration and lack of independence when compared to different age groups between 13-19 years. From the results, it can be concluded that though this study didn't support the studies done before completely and being accepted only a few sub variables, it is evident that the study variables (emotional intelligence, emotional maturity and altruistic behavior) have certain effects on each other. 


\section{International Advanced Research Journal in Science, Engineering and Technology}

Vol. 8, Issue 6, June 2021

DOI: $10.17148 /$ IARJSET.2021.86115

\section{REFERENCES}

[1] Binet A. (1909) 'Modern Ideas about children' Referred from Furnandez P. and Berrocal P. www.unioviedo.net $\backslash$ reunidolindex pdf $\backslash$ pst

[2] Bhalla \& Naurliyar, D.K. (2004) Emotional Intelligence, The Emerging Paradigm in Personal Dynamics, Psychology Studies. 49,97 - 105.

[3] Brackett, M.A.; Lopez, P.N.; Luceviz, Z.; Mayer, J.D. and Salovey,P. (2004): Integrating emotion and cognition, the role of Emotional intelligence, in D Dai and R J Strenberg (Edn) Motivation, emotion and cognition. Integrating perspective on intellectual functioning, pp 175194 Mahwah, N. J. Lawrence Eelbaum.

[4] Gupta, S.B. (2009): Emotional intelligence of senior secondary students in relation to their reasoning ability. Journal of Education Studies, 7 (1),

[5] Goleman, D. (1995) Emotional Intelligence, New York, Bantam.

[6] Goleman, D. (1998) Working with Emotional Intelligence, New York, Bantam.

[7] Singh, D. (2007) Emotional Intelligence at Work, Response Books, New Delhi.

[8] Bindu, P. and Thomas, I. (2006) Gender difference in Emotional Intelligence, National Academy of Psychology, $51,261-168$.

[9] Malviya, S. (2007): A study of emotional intelligence in relation to moral judgement secondary school students. M.Ed. Dissertation, University of Allahabad.

[10] Singh, M. O.; Chaudhary, P. and Asthana, M. (2008): Impact of Locale and Gender on Emotional Intelligence of Adolescents. Psycho Linguistic Association, 2008, 38(1): $52-56$

[11] Mayer, J.D., Salovey, P. \& Caruso, D.R. (2000) Models of emotional intelligence. In R. J. Sternberg (Ed.). Handbook of Intelligence (pp 396420) Cambridge, England: Cambridge University Press.

[12] Mayer, J.D. (2001) A field guide to emotional intelligence. In J. Ciarrochi, J.P. Forgas \& J.D. Mayer (Eds.), Emotional Intelligence and Every Day Life (pp 3-24). New York, Psychology Press.

[13] Sanwal, V. (2004). Emotional Intelligence: The Indian Scenario, New Delhi, Indian publisher Distributers.

[14] Marriadoss, J. S. (2000) 'Emotional intelligence Tool of credibility' University News ,38(12), March $20 \mathrm{pp}$ 7-11.

[15] Sternberg R. (1988): (ed.), Internal Constraints: Handbook of Human Intelligence, Cambridge: Cambridge University Press, 1988.

[16] Mark-Allen, J. (2005): Relationship between emotional intelligence and personality factors in community based sample. Dissertation Abstracts International, 66(6), $3456 \mathrm{~B}$.

[17] Manhas, K.D. and Gakhar, S.C. (2005): Cognitive Correlates of Emotional Intelligence of Adolescents. Ram-Eesh Journal of Education, Vol. 2(2), 78 - 83. (Indian Educational Abstracts January and July 2005, p. 7 - 8). 